\title{
Nursing Facility Certified Under Medicaid but Not Certified Under Medicare
}

National Cancer Institute

\section{Source}

National Cancer Institute. Nursing Facility Certified Under Medicaid but Not Certified Under Medicare. NCI Thesaurus. Code C99913.

A medical center which is eligible to receive funding from Medicaid but not Medicare. (ACC) 